\title{
Using Blended Learning to Develop Skills of Google Application for Teachers of Prep Schools
}

\author{
Prof / Moustafa Abdelkhalek ${ }^{1}$, Ibrahim Mesha'l Alenezi ${ }^{2}$ \\ ${ }^{1}$ Professor of Instructional Technology, \\ Manager of Digital Design and Publishing Research Unit (DDPRU) \\ Faculty of Education, \\ Tanta University, Egypt \\ ${ }^{2} \mathrm{Ph} . \mathrm{D}$. Researcher Instructional Technologies, \\ Faculty of Education, \\ Tanta University, Egypt
}

\begin{abstract}
The Current Study Aims At Investigating The Effect of Blended Learning on Developing Skills of Using Google Applications For Computer Teachers At Prep Schools. Research Sample Included (30) Computer Teachers Who Were Chosen Randomly From Al Ga'hra' Educational Administrations In Kuwait .Research Implements Are Represented In A Test of Cognitive Aspect To Measure Skills Of Google Applications (Google Drive), A Card To Measure The Previous Skills Besides Holding Sessions To Practice Sharing Files And Photos Via Google Drive . After Applying Implements And Experiment of The Research, There Were Differences With Statistical Significance Between The Pre And Post Applications At The Favor Of The Post One In Both Grades of The Test And The Skill Card Of Cognitive Aspect of Google Application Skills (Google Drive).
\end{abstract}

Keywords: Blended learning, Google applications, Google Drive, teachers of prep schools

\section{Introduction}

To The Idea Of The Blended Learning Is To Correlate Between Classical And Electronic Styles Of Learning To Do Progress In The Educational Process. For The Importance of The Blended Learning, Curricula Were Reconsidered To Go Along With New Requirements of Information Age, Hence A Big Deal Of Care For Training Persons To Use Information Technology (Al Sherman, 2013). Blended Learning Makes A Student The Axis of The Educational Process Instead Of A Teacher As We See In Classical Education (Salim, 2004). (Khames, 2003) Defines Blended Learning As An Integrated System To Help Learners During Their Educational Stages By Blending Classical Education And Electronic One Inside Classes. (Ismael, 2009) Argues That Blended Learning Is A Process of Employing Technological Innovations To
Blend Content, Aims And Learning Activities For Making Interaction Between Teachers And Learners. (Dzuban \&Moskal, 2001) See That Blended Learning Help In Improving Learning Environment Because It Serves Opportunities For Learners To Use Many Technological Techniques During Learning To Achieve Educational Goals. Moreover, Blended Learning Encourages Learners To Get Information By Participating In Individual Activities And Cooperative Projects (Positive Role) Instead of Dictation And Memorizing (Negative Role). Charles, 2005 Sees That It Is Necessary For Designers of Curricula To Blend The Classical Ways And Electronic Ones To Upgrade Learners' Levels. Blended Learning Was Surrounded By Many Studies To Test Its Effectiveness on Developing Outputs Of Learning. One of These Studies Was (Al Agramy's ,2016) Study Which Explored Effectiveness Of Blended Learning On Developing Skills of Maintaining Computers For Students 
At Al Aqsa University. Results Showed Differences With Statistical Significance of The Cognitive And Skillful Aspect In The Post Application of Study Implements Due To Using Blended learning. The study recommended adopting using blended learning inside technology department in Al Aqsa University and other Universities. ( Said's, 2014 )referred to importance of blended learning. The study focused on exploring the effectiveness of using second generation of web applications on upgrading skills of maintaining computers for students at faculty of qualitative education, Zaga Zing University at section of preparing computer teachers, besides evaluating their trends towards blended learning. Results proved that blended learning is effective in increasing students' skills and achievements in computer maintenance. Petersen, 2013 confirmed that Google Company served many free applications which are used on a large scale to support educational purposes and satisfy students' needs. Google apps helps teachers to produce digital curricula which facilities connection between students and teachers. (Al Dalaan, 2017) sees that Google apps are a collection of services and apps which are employed synchronically or non-synchronically through uploading free lectures and achieving communication .(waheed ,2016) defines Google apps as a collection of free services such as Gmail, Google doc, Google calendar, Google plus, Google sites and Google talk. (Al Said, 2013) sees that Google educational apps have a lot of merits: applications don't need to be installed on the pc of users; they save documents automatically and do without printing. Besides, Google applications serve storing capacity for users freely and enable students and teachers to change any document to a web page. Google applications are safe and not accessible by not-allowed users. They also serve privacy for data and information and don't need learning programming languages. (Al qahtany \& Al Fahd, 2017) define Google applications as a free collection of apps which are served by Google Company trying to make interaction between teachers and students. Google cloud applications are described by simplicity and easiness for users. (Haitham $\&$ Tolba, 2017) summarized the advantages of Google applications as follow: automatic saving for all changes every 5 seconds which mean keeping projects and works in any condition, possibility of organizing content and using ready templates and files. In addition, Google applications can be accessible online or offline. Google company offers technical support for all its applications such as educational videos and data base which can be researched by keywords and finding solutions for any problem facing users.

\section{Methodology}

The Current Research Aims At Developing Skills of Google Applications (Google Drive) To Practice Sharing Files And Photos For Teachers of Prep Schools. These
Skills Should Be Included During Preparing Skillful Courses Which Support A Teacher's Role During Teaching Process. Research Sample Included (30) Computer Teachers Who Were Chosen Randomly From (Al Ga'hra' Educational Administrations In Kuwait) .Research Implements Are Represented In A Test of Cognitive Aspect To Measure Skills of Google Applications (Google Drive), A Card To Measure The Previous Skills Besides Holding Sessions To Practice Sharing Files And Photos Via Google Drive In The Second Term of The Year (2018/2019). The Research Tried To Test Two Assumptions. First One Is That There Is No Statistically Significant Difference At Level (0. 05) Between Means of Experimental Group Grades In The Pre And Post Application of A Blended Training Program For Computer Teachers In The Cognitive Aspect Test And A Measure Card of Google Drive At The Favor of The Post Application. (SPSS) Program Was Used To Analyze Results.

\section{Results}

(T-Test) Was Used To Calculate Differences Between Grades of The Pre And Post Application For Cognitive Aspect Measure Test of Google Drive App )As The Following Table Shows:

Table (1) Difference between means of pre and post tests after testing cognitive aspect of Google drive app for experimental group by T-Test.

\begin{tabular}{|l|l|l|l|l|l|}
\hline Group & Means & $\begin{array}{c}\text { Standard } \\
\text { deviation }\end{array}$ & $\begin{array}{l}\text { Degree of } \\
\text { freedom }\end{array}$ & $\begin{array}{c}\text { T } \\
\text { value }\end{array}$ & Significant \\
\hline Pre & 4.55 & 2.064 & 29 & 48.2 & 0,05 \\
\hline post & 16.95 & 1.57 & & & \\
\hline
\end{tabular}

Table (1) Demonstrates That Calculated Value of "T" In Cognitive Test Was 48.2 Which Is Higher Than Table Value Of "T" (0.05)

T-Test Was Used To Calculate Differences Between Grades of The Pre And Post Application In The Skill Card For Google Drive Apps As The Following Table Shows:

Table (2) Results of Grade Means for Experimental Group In The Pre Application of Observation Card Concerning Skillful Aspect of Google Drive By Using T-Test

\begin{tabular}{|l|l|l|l|l|l|}
\hline Group & Means & $\begin{array}{l}\text { Standard } \\
\text { deviation }\end{array}$ & $\begin{array}{l}\text { Degree of } \\
\text { freedom }\end{array}$ & $\begin{array}{l}\mathrm{T} \\
\text { value }\end{array}$ & Significant \\
\hline post & 53.40 & 2.79 & 29 & 85.3 & 0,05 \\
\hline
\end{tabular}

Table (2) Demonstrates That Calculated Value of "T" In The Skill Card Was 85, 3 Which Is Higher Than Table Value Of "T" $(0,05)$

\section{Discussion}

The Previous Findings Prove That Blended Learning Has An Effective Impact on Developing Skills of Google 
Drive Application For Computer Teachers Regarding The Following Reasons:

1- Carrying Out Blended Learning Led To Positive Participation For Teachers During Practicing Google Drive Application Skills.

2- Blended Learning Increases Mutual Interaction between Teachers.

3- Blended Learning Help Teachers During Steps of Implementing It To Select Better Contents.

4- The More Accurate and Brief Stages of Implementing Blended Learning Are, The Better Results Are Achieved.

\section{Conclusion}

Considering Blended Learning one of The Most Important Educational Strategies, It Is A Must To Use It In Training Students on Technological Skills

\section{Recommendations}

- The Need To Pay Attention To Blended Learning As A Successful Educational Strategy In The Educational Process

- Blended Learning Is A Good Way To Achieve Educational Goals

- The Necessity of Training Teachers on Blended Learning Systems And How To Use Them In The Educational Process

- Google Applications Have A Strong Impact In Achieving Educational Goals, So It Is Necessary To Train Teachers on Their Use Skills.

\section{References}

[1] Ahmed Salem. (2004). E-learning technology. Riyadh: Al-Rushd Library.

[2] AlGhareeb \& Ismail. (2009). E-learning from the app to professionalism and quality. Cairo: The World of Books.

[3] Iman Al-Dulaan. (2017). The effect of using Google educational applications on developing electronic test design skills for female educational diploma students in the computer course in education. Jordan: The Specialized International Educational Journal.

[4] Turki Al-Qahtani, Abdullah bin Suleiman Al-Fahd. (2017). Requirements for the employment of interactive Google applications in teaching computer subject for high school from the teachers point of view in Riyadh. Egypt: The World of Education.

[5] Atef Al-Sharman. (2013). Contemporary education technology and curriculum development. Amman: Wael House for Publishing and Distribution.

[6] Mohamed Khamis. (2003). Education technology products. Cairo: Dar Al-Hekma.
[7] Muhammad Waheed. (2016). Developing a participatory learning strategy based on Google's educational applications and its impact on developing e-courses design skills and their direction among the faculty members at Bisha University. Saudi Arabia: Arab Studies in Education and Psychology.

[8] Nabil El-Sayed. (2013). The effect of the use of participatory learning based on Google educational applications in developing electronic skills design skills and the direction towards it among faculty members at Umm Al-Qura University. Alexandria: Journal of the Faculty of Education.

[9] Haitham Hassan \& Reham Tolba. (2017). Cloud computing applications in education. Cairo: Arab Academic Center for Publishing and Distribution.

[10] Charles. (2005). Blend Learning Systems, Defintion, Current trend, and fayure Direction.

[11] Dzuban \& Moskal. (2001). Distributed learning impact Evaluation.

[12] Petersen. (2013). An Introduction and Overview to Google Apps inK12 Education: A Web-based Instructional Module 